\title{
THE GROSS MOTOR SKILL CHILDREN WITH MILD MENTAL RETARDATION
}

\author{
${ }^{1 *}$ M. Haris Satria, ${ }^{2}$ Khoirul Andrianto \\ Correspondence: Universitas Bina Darma, Palembang, Indonesia \\ E-mail: haris@binadarma.ac.id
}

\begin{abstract}
This study aims to determine the level of gross motor skills of children with mild mental retardation in SD SLB C Karya Ibu Palembang. The type of research in this thesis is qualitative research with quantitative descriptive research methods. The sample in this study were mild mental retardation children from grade I to VI at SD SLB C Karya Ibu Palembang. Instrument test used Test of Gross Motor Development (TGMD) consists of 12 test items, namely run, gallop, hop, leap, horizontal jump, slide, striking stationary ball, stationary dribble, catch, kick, overhand throw and underhand roll The results of measuring the motor skills of students at SD SLB C Karya Ibu Palembang, namely "ASP" got the category below average, "BNP" got the average category, "BSA" got the bad category, "DAS" got the bad category, "DIG" got the category below average, "FRI" got a below average category, "IAN" got a bad category, "KAN" got a bad category, "LEN" got a below average category, and "MAN" got a below average category. The conclusion in this study is that the level of gross motor skill of children with mild mental retardation in Elementary School Extraordinary School Karya Ibu belongs to the category below average.
\end{abstract}

\section{Keywords: Groos Motor Skill, Mild Mental Retardation \\ Introduction Jurnat Physicalleduc Mental Retardation}

Children are unique individuals, as unique individuals children need to get attention from all aspects of the child's life. One thing that must be considered is the development that takes place in the child's life. Development is a change that starts from conception and continues in the development of each individual (Febrialismanto, 2017: 1).

Deaf children are children who have intellectual disorders that cause difficulty to adapt to their environment. The number of children with visual impairment is estimated at $2.5-3 \%$ of the general population. According to its characteristics, approximately $85 \%$ of children with mild mental retardation from the existing visually impaired population. These children can be taught academically approximately until grades 4,5 and 6 . They can also be children who have confidence, be independent, communicate and interact socially well, if the social environment provides support (Gadis Mulia Wati, 2012:69). This data is also supported by data from Kemis and Ati (2013:11) that the number of people with visual impairment is $1.92 \%$ who are school-age children with a ratio of $60 \%$

PJKR

https://jurnal.unimed.ac.id/2012/index.php/jpehr 
men and women $40 \%$ or 3:2. In the main data of extraordinary schools seen from the school age group, the number of people in Indonesia who bear abnormalities is $48,100,548$ people, so the estimated number of people in Indonesia who have visual impairment is $2 \% \mathrm{x} 48,100,548$ people $=962,011$ people .

Children with mentally retarded have the same rights to obtain proper education, as mandated in the 1945 Constitution Article 31 paragraph 1 which reads "Every citizen has the right to get a proper education". This is made clear in Law No. 20 of 2003 on the National Education System. The Law states things that are closely related to education for children with special needs. The contents are as follows:

"Chapter IV (article 5 paragraph 1) which states that every citizen has the same right to obtain a good quality education who has physical, emotional, mental, intellectual and / or social disabilities, has the right to special education".

"Chapter VI, part 11 of Special Education (article 32 paragraph 1) which reads special education for participants who have a difficulty level in following the learning process because of physical, emotional, mental, social or intellectual disabilities".

Educational services for children with special needs in this case are mentally retarded children organized by Special Schools (Elementary Schools and Junior/Senior High Schools). In the learning process, the school implements learning based on student needs, including the need for motor development. This is because the motor development of mentally retarded children is impaired compared to other common children. This is made clear by Yani and Asep (2013: 24) that almost all types of disabilities with special needs have psychomotor problems. Psychomotor problems as a result of limited sensomotor abilities and limitations in learning abilities.

Motor skills consist of gross motor skills and fine motor skills. This is in line with the opinion of Samsudin (2008: 11) which states that motor development is divided into two, namely (1) gross motor skills where the movement uses large muscles which include basic locomotor, non-locomotor and manipulative basic movements, and (2) motor Smooth is the ability of preschool children to move using smooth muscles (small muscles) such as writing and drawing. Furthermore, according to Masganti (2015: 95), motor skills are divided into two, namely (1) gross motor skills are the ability to change body position, and (2) fine motor skills) are the ability to coordinate hands and eyes.

For this reason, it is necessary to know the level of motor skills of mentally retarded children in order to help them improve their motor skills. In this study, researchers will focus on the gross motor skills of children with mild mental retardation. This research will be carried out in the Elementary School of Ibu Karya Extraordinary School C in Palembang. 


\section{Method}

This research is a descriptive research, where in this study researchers will describe the gross motor skill in elementary school students of Extraordinary School part $\mathrm{C}$ in Palembang. The samples in this study were children with mild mental retardation at The Elementary School of Extraordinary School part C in Palembang. The test instrument used to collect data is the Test of Gross Motor Development (TGMD) from Ulrich (2000). Test of Gross Motor Development (TGMD) is a test that aims to measure fundamental movement especially gross motor skill of children aged 3 to 10 years. The gross motor skills test consists of 12 test items, namely run, gallop, hop, leap, horizontal jump, slide, striking stationary ball, stationary dribble, catch, kick, overhand throw and underhand roll.

\section{Discussion}

Before The data from this study consisted of data on students' gross motor skills. The gross motor skills test consists of 12 test items, namely run, gallop, hop, leap, horizontal jump, slide, striking stationary ball, stationary dribble, catch, kick, overhand throw and underhand roll. The following is the data on the measurement of gross motor skills of students at SD SLB C Karya Ibu Palembang which is described as follows:

Description of TGMD Test Results for "ASP"

The following are the results of the TGMD test for "ASP" which can be seen in the table below:

Table 1. Results TGMD Test For "ASP"

\begin{tabular}{|c|c|c|c|c|}
\hline \multirow{2}{*}{ Test } & \multicolumn{2}{|c|}{ First Test } & \multicolumn{2}{|c|}{ Second Test } \\
\hline & Raw Score & Standart score & Raw Score & Standart score \\
\hline \multicolumn{5}{|c|}{ 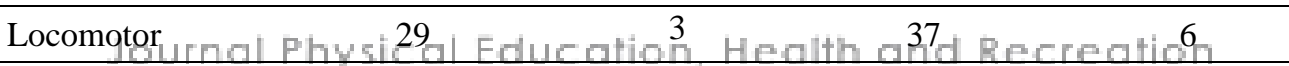 } \\
\hline Object Control & 26 & 2 & 28 & 3 \\
\hline Total & $\operatorname{locosecten}$ & 5 & & 9 \\
\hline
\end{tabular}

Based on the test results obtained that the number of first test results standard score 5 and the number of test results of the second standard score 9, then the total standard score is 14. Furthermore, the total result calculated with table $\mathrm{C} 1$ is obtained by 82 . Calculation results show that gross motor skill of "ASP" fall into the category of below average description.

Description of TGMD Test Results for "BNP"

The following are the results of the TGMD test for "BNP" which can be seen in the table below:

PJKR_

https://jurnal.unimed.ac.id/2012/index.php/jpehr 
Table 2. Results TGMD Test For "BNP"

\begin{tabular}{lcccc}
\hline \multirow{2}{*}{ Test } & \multicolumn{2}{c}{ First Test } & \multicolumn{2}{c}{ Second Test } \\
\cline { 2 - 5 } & Raw Score & Standart score & Raw Score & Standart score \\
\hline Locomotor & 27 & 3 & 33 & 5 \\
\hline Object Control & 34 & 5 & 35 & 5 \\
\hline Total & & 8 & & 10 \\
\hline
\end{tabular}

Based on the test results obtained that the number of first test results standard score 8 and the number of test results of the second standard score 10, then the total standard score is 18. Furthermore, the total result calculated with table $\mathrm{C} 1$ is obtained by 94 . Calculation results show that gross motor skill of "BNP" fall into the category of average description.

Description of TGMD Test Results for "BSA"

The following are the results of the TGMD test for "BSA" which can be seen in the table below:

Table 3. Results TGMD Test For "BSA"

\begin{tabular}{lcccc}
\hline \multirow{2}{*}{ Test } & \multicolumn{2}{c}{ First Test } & \multicolumn{2}{c}{ Second Test } \\
\cline { 2 - 5 } & Raw Score & Standart score & Raw Score & Standart score \\
\hline Locomotor & 24 & 2 & 27 & 3 \\
\hline Object Control & 32 & 4 & 31 & 4 \\
\hline Total & & 6 & & 7 \\
\hline
\end{tabular}

Based on the test results obtained that the number of first test results standard score 6 and the numben of test results of the second standard score 7 , then the total standard score is 13 . Furthermore, the total result calculated with table $\mathrm{C} 1$ is obtained by 79 . Calculation results show that gross motor skill of "BSA" fall into the category of bad description.

Description of TGMD Test Results for "DAS"

The following are the results of the TGMD test for "DAS" which can be seen in the table below:

Table 4. Results TGMD Test For "DAS"

\begin{tabular}{lcccc}
\hline \multirow{2}{*}{ Test } & \multicolumn{2}{c}{ First Test } & \multicolumn{2}{c}{ Second Test } \\
\cline { 2 - 5 } & Raw Score & Standart score & Raw Score & Standart score \\
\hline Locomotor & 23 & 1 & 28 & 3 \\
\hline Object Control & 25 & 2 & 31 & 4 \\
\hline Total & & 3 & & 7 \\
\hline
\end{tabular}

PJKR

https://jurnal.unimed.ac.id/2012/index.php/jpehr 
Based on the test results obtained that the number of first test results standard score 3 and the number of test results of the second standard score 7, then the total standard score is 10. Furthermore, the total result calculated with table $\mathrm{C} 1$ is obtained by 70 . Calculation results show that gross motor skill of "DAS" fall into the category of bad description.

Description of TGMD Test Results for "DIG"

The following are the results of the TGMD test for "DIG" which can be seen in the table below:

Table 5. Results TGMD Test For "DIG"

\begin{tabular}{lcccc}
\hline \multirow{2}{*}{ Test } & \multicolumn{2}{c}{ First Test } & \multicolumn{2}{c}{ Second Test } \\
\cline { 2 - 5 } & Raw Score & Standart score & Raw Score & Standart score \\
\hline Locomotor & 30 & 4 & 31 & 4 \\
\hline Object Control & 34 & 5 & 34 & 5 \\
\hline Total & & 9 & & 9 \\
\hline
\end{tabular}

Based on the test results obtained that the number of first test results standard score 9 and the number of test results of the second standard score 9, then the total standard score is 18. Furthermore, the total result calculated with table $\mathrm{C} 1$ is obtained by 94 . Calculation results show that gross motor skill of "DIG" fall into the category of average description.

Description of TGMD Test Results for "FRI"

The following are the results of the TGMD test for "FRI" which can be seen in the table below:

Journal Physical Education. Health and Recreation

Table 6. Results TGMD Test For "FRI"

\begin{tabular}{lcccc}
\hline \multirow{2}{*}{ Test } & \multicolumn{2}{c}{ First Test } & \multicolumn{2}{c}{ Second Test } \\
\cline { 2 - 6 } & Raw Score & Standart score & Raw Score & Standart score \\
\hline Locomotor & 27 & 3 & 24 & 2 \\
\hline Object Control & 34 & 5 & 32 & 4 \\
\hline Total & \multicolumn{5}{c}{} \\
\hline
\end{tabular}

Based on the test results obtained that the number of first test results standard score 8 and the number of test results of the second standard score 6 , then the total standard score is 14. Furthermore, the total result calculated with table $\mathrm{C} 1$ is obtained by 82 . Calculation results show that gross motor skill of "FRI" fall into the category of below average description.

Description of TGMD Test Results for "IAN"

The following are the results of the TGMD test for "IAN" which can be seen in the table below:

PJKR_

https://jurnal.unimed.ac.id/2012/index.php/jpehr 
Table 7. Results TGMD Test For "IAN"

\begin{tabular}{lcccc}
\hline \multirow{2}{*}{ Test } & \multicolumn{2}{c}{ First Test } & \multicolumn{2}{c}{ Second Test } \\
\cline { 2 - 5 } & Raw Score & Standart score & Raw Score & Standart score \\
\hline Locomotor & 24 & 2 & 27 & 3 \\
\hline Object Control & 32 & 4 & 31 & 4 \\
\hline Total & & 6 & & 7 \\
\hline
\end{tabular}

Based on the test results obtained that the number of first test results standard score 6 and the number of test results of the second standard score 7 , then the total standard score is 13. Furthermore, the total result calculated with table $\mathrm{C} 1$ is obtained by 79 . Calculation results show that gross motor skill of "IAN" fall into the category of bad description.

Description of TGMD Test Results for "KAN"

The following are the results of the TGMD test for "KAN" which can be seen in the table below:

Table 8. Results TGMD Test For "KAN"

\begin{tabular}{lcccc}
\hline \multirow{2}{*}{ Test } & \multicolumn{2}{c}{ First Test } & \multicolumn{2}{c}{ Second Test } \\
\cline { 2 - 5 } & Raw Score & Standart score & Raw Score & Standart score \\
\hline Locomotor & 26 & 2 & 27 & 3 \\
\hline Object Control & 28 & 3 & 31 & 4 \\
\hline Total & & 5 & & 7 \\
\hline
\end{tabular}

Based on the test results obtained that the number of first test results standard score 5 and the numben of test results of the second standard score 7 , then the total standard score is 12 . Furthermore, the total result calculated with table $\mathrm{C} 1$ is obtained by 76 . Calculation results show that gross motor skill of "KAN" fall into the category of bad description.

Description of TGMD Test Results for "LEN"

The following are the results of the TGMD test for "LEN" which can be seen in the table below:

Table 9. Results TGMD Test For "LEN"

\begin{tabular}{lcccc}
\hline \multirow{2}{*}{ Test } & \multicolumn{2}{c}{ First Test } & \multicolumn{2}{c}{ Second Test } \\
\cline { 2 - 5 } & Raw Score & Standart score & Raw Score & Standart score \\
\hline Locomotor & 28 & 3 & 30 & 4 \\
\hline Object Control & 31 & 4 & 32 & 4 \\
\hline Total & & 7 & & 8 \\
\hline
\end{tabular}

PJKR

https://jurnal.unimed.ac.id/2012/index.php/jpehr 
Based on the test results obtained that the number of first test results standard score 8 and the number of test results of the second standard score 7 , then the total standard score is 15 . Furthermore, the total result calculated with table $\mathrm{C} 1$ is obtained by 85 . Calculation results show that gross motor skill of "LEN" fall into the category of below average description.

Description of TGMD Test Results for "MAN"

The following are the results of the TGMD test for "MAN" which can be seen in the table below:

Table 10. Results TGMD Test For "MAN"

\begin{tabular}{lcccc}
\hline \multirow{2}{*}{ Test } & \multicolumn{2}{c}{ First Test } & \multicolumn{2}{c}{ Second Test } \\
\cline { 2 - 5 } & Raw Score & Standart score & Raw Score & Standart score \\
\hline Locomotor & 33 & 4 & 35 & 5 \\
\hline Object Control & 29 & 3 & 31 & 4 \\
\hline Total & & 7 & & 9 \\
\hline
\end{tabular}

Based on the test results obtained that the number of first test results standard score 7 and the number of test results of the second standard score 9, then the total standard score is 16. Furthermore, the total result calculated with table $\mathrm{C} 1$ is obtained by 88 . Calculation results show that gross motor skill of "MAN" fall into the category of below average description.

The results of a rough motor ability test from 10 children showed that overall the gross motor-skill of children with mild mental retardation in Elementary School Extraordinary School Karya Ibu was in the below average category. This result is certainly not the final result of the level of gross motor skill of ehildren with mild mental retardation, but a pieture of the gress motor skill of children with mild mental retardation. Many factors that affect the test results include seriousness, motivation, boredom, understanding of the implementation of the test, the atmosphere in the implementation of the test and others. This is in line with the results of a study from Fredi Tri Widianto (2012:15) which said that the test results carried out against SMPLB Negeri Semarang part C were influenced by several factors, including the lack of ability of students in understanding the commands or instructions given by researchers and the lack of speed of students to respond to stimulus coming from outside, so that the results of the student's fundamental movement skills test were less than optimal. This is due to the mental retardation carried by the students. Furthermore, in the research Haris and Agus (2019:53) stated that in addition to mentoring and instruction from teachers that should be emphasized more is mentoring the personal of children with mild mental retardation because they have an unstable emotional and rapidly changing.

Therefore, teachers must understand the characteristics of their students so that in the implementation of learning for children with mild mental retardation must be adjusted to their characteristics. If the teacher understands and realizes it,

PJKR

https://jurnal.unimed.ac.id/2012/index.php/jpehr 
the learning will be meaningful for children with mild mental retardation that are useful for their daily lives.

\section{Conclusion}

Based The conclusion in this study is that the level of gross motor skill of children with mild mental retardation in Elementary School Extraordinary School Karya Ibu belongs to the category below average.

\section{References}

Febrialismanto 2017. Gambaran Motorik Kasar Anak Usia 4-5 Tahun Di TamanKanak-Kanak Kecamatan BangkinangKabupaten Kampar Propinsi Riau. Jurnal Pesona Dasar Vol. 5 Edisi : 2, 1-15.

Fredi Tri Widianto . 2012. "Keterampilan Gerak Dasar Anak Tunagrahita Ringan". Journal of Physical Education, Sport, Health and Recreation, Volume : 1, Edisi : 1, 11-15.

Gadis Mulia Wati. 2012.Outbound Management Training Untuk MeningkatkanKemampuan Penyesuaian Diri Anak Tunagrahita. Educational Psychology Journal. Volume : 1 Edisi : 1, 68-74.

Kemis dan Rosnawati, Ati. 2013. Pendidikan Anak Berkebutuhan Khusus Tunagrahita. Bandung: PT. Luxima Metro Media.

Haris, M. Satria \& Agus, Made Wijaya. 2020. "Permainan Gerak Dasar Lokomotor Untuk Anak Tunagrahita Sedang”. Jurnal Penjakora. Volume : 7, Edisi : April, 49-56.

Meimulyani, Yani dan Tiswara, Asep . 2013. Pendidikan Jasmani Adaptif. Jakarta: PT. Luxima Metro Media.

Samsudin. 2008. Pembelajaran Motorik di Taman Kanak-Kanak. Jakarta: Prenada Media Group.

Sit, Masganti. 2015. Psikologi Perkembangan Anak Usia Dini Jilid I. Medan: Perdana Publishing.

Undang-Undang Dasar 1945. Pasal 31 ayat 1.

Undang-Undang No 20 Tahun 2003 tentang Sistem Pendidikan Nasional

Ulrich, Dale A. 2000. Test of Gross Motor Development (second edition). Austin : Shoal Creek Boulevard. 